\title{
Art and everydayness: Popular culture and daily life in the communist Czechoslovakia
}

European Journal of Cultural Studies 15(6) 703-720 (c) The Author(s) 2012 Reprints and permissions: sagepub.co.uk/journalsPermissions.nav DOI: 10.1177/1367549412450637 ecs.sagepub.com

@SAGE

\section{Daniel Just}

Bilkent University, Turkey

\begin{abstract}
This article analyzes the interaction between art and practices of everyday life in communist Czechoslovakia in the 1970s and 1980s. Discussing various forms of adaptations to the politically repressive system - from photography and film to social activities such as 'cottage homemaking' and 'cabining' - the author describes ways in which popular culture under communism resisted the state-induced drive to modernize which, as a political tool, was designed to pacify the masses. The article suggests that by breaching the gap between the quotidian and the extraordinary, which as a systemic division has defined daily life in modernity, popular culture was instrumental in reinvigorating everydayness.
\end{abstract}

\section{Keywords}

Communism, everyday life, modernity, ordinariness, popular culture

\section{Introduction}

Notoriously difficult to isolate and describe, everydayness does not go well with art. Problems with portraying everyday life are manifold and in no way limited to the oftrepeated concern about the realism of its representation. In fact, the question of truthfulness of the depicted reality when it comes to daily life hinges on a more fundamental question, whether art in its effort to foreground everyday life does not transcend it, thus stripping it of its everydayness and whether art that remains within the realm of the daily

\section{Corresponding author:}

Daniel Just, Department of Political Science, Bilkent University, 06800 Ankara, Turkey.

Email: just@bilkent.edu.tr 
does not merely reproduce the banality of the everyday, thus running the risk of collapsing into an artless triviality. Art that relates everydayness has to be, as it were, neither too artistic nor not artistic enough. As a form of representation it has to embrace the paradox of showing things anew, yet making it clear that they are anything but. Or, as Michael Sheringham put it recently, it has to make 'the act of perception performative rather than merely constative', all the while undermining its performativity and drawing attention to the fact that 'the performance of perception remains actually constative because what it renders visible is in fact already there' (2006: 82). The particular case of communist Eastern Europe in the 1970s and 1980s does not immediately strike one as having much new to offer to this dilemma. Due to the political circumstances that turned all daily activities into various forms of adaptations to the status quo, it would seem that artistic representations of everydayness could be either a covert propaganda or, in case they refused to leave the ordinariness of the daily, outright banality. However, this was not always the case. In Czechoslovakia, for example, where a large portion of popular culture during these two decades turned to everyday life and its depiction, the result was an art that was neither politically compliant nor aesthetically obtuse.

Although all Czechoslovak popular art in the 1970s and 1980s repositioned itself visà-vis the quotidian, the shift was most manifest in film and photography. Often no more than an extension of a broad base of amateur photographers operating in non-metropolitan areas, popular photography focused on mundane situations, prosaic locales and people with unrefined personal appearances in an attempt to foreground ordinariness and the unexceptionality of the depicted material. As evident from Jindřich Štreit's images of common villagers in Silesia, the choice of events from daily life that for most people were easy to recognize and relate to was far from the cheerful situations and exaltations of modernity that dominated the official art (see Figures 1 and 2).

In spite of the overall greyness and sombreness of the represented events, these pictures had little to do with social critique or political commentary. Although Štreit found his subject matter mostly in rural areas, his photographs did not evoke an imagined purity and simplicity of pre-modern existence as a way of critically opposing modernization or drawing attention to the regions forgotten by it. With a very low level of stylization, these images deliberately downplayed the act of representation, thereby relinquishing any diagnostic role and critical function. Rather than pointing to a higher level of interpretation by opening the play of fantasy or the movement of defamiliarization and subsequent projection of some poetic element onto the depicted everydayness, Štreit's pictures insisted on the density and completeness of what they portrayed. With no closeups, extreme angles and artificial lighting, the type of aesthetic that these photographs created displayed their unadornment, and with only a minimal level of creative figuration - the arrangement of objects along diagonal lines, for example - conveyed everyday life in a pseudo-documentary fashion, emphasized by captions with the years and names of places.

However, despite their poetic flatness, Štreit's photographs were not purely indexical documents. Instead of extending the problematic vision of 'documentary realism as truth' by naively believing in an unmediated access to reality, these photographs related to everyday life by relying on the meanings implied in the material that they featured. Unlike the state-sponsored portrayal of either workers or private consumers, which as an 


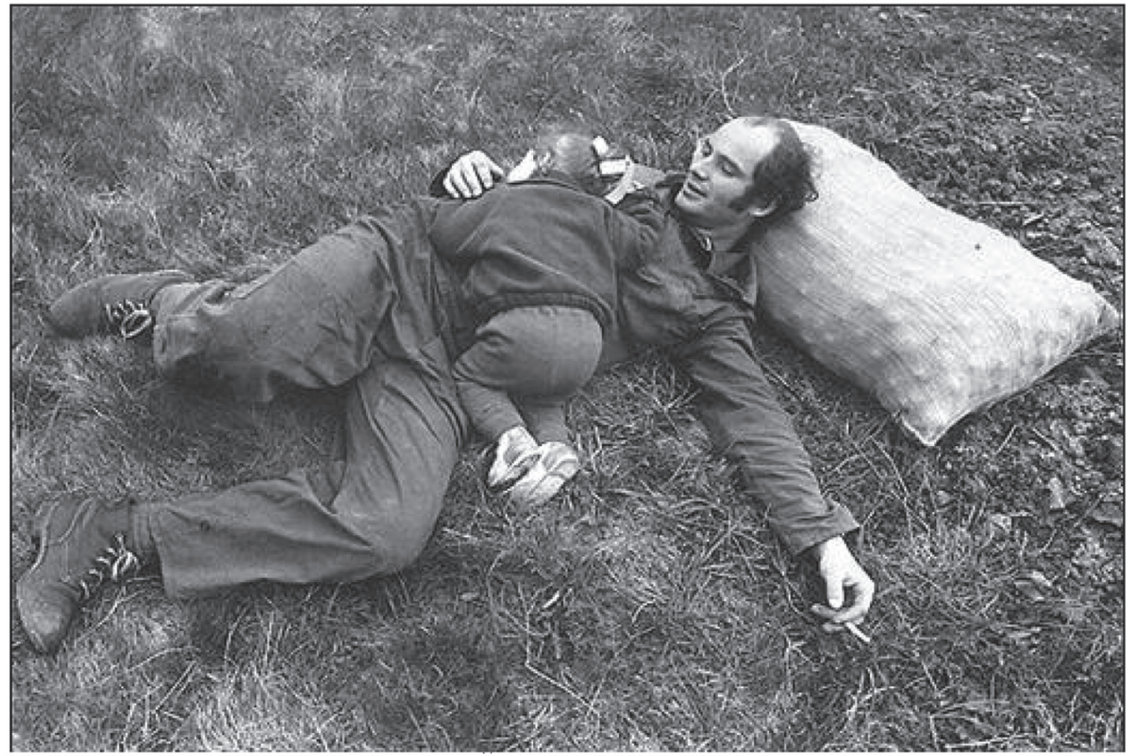

Figure 1. Těchanov (Jindřich Štreit, 1981) (Reproduced with kind permission of Jindřich Štreit)

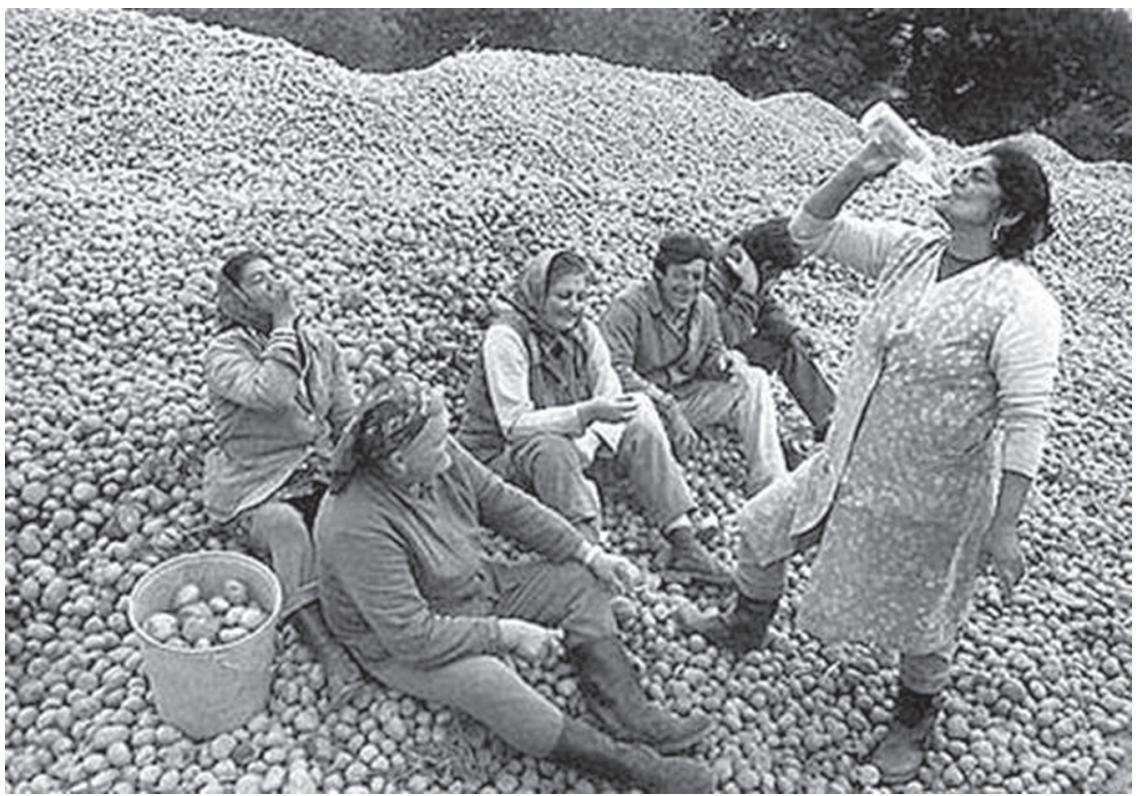

Figure 2. Arnoltice (Jindřich Štreit, 1979) (Reproduced with kind permission of Jindřich Štreit) 
aesthetic norm supplemented the newly-introduced social division between the private and the public, Štreit's photographs destabilized the prevailing social and pictorial conventions by capturing those with manual jobs in industry and agriculture in a setting that defied the divide between workplace and domestic space. In his pictures - but one could find other examples, such as Viktor Kolář's photographs from the Ostrava region people perform their daily deeds in a milieu that is public, but in which work blends with the social and the family bonding to such an extent that the private and the communal lose their clearly defined boundaries. What is more, it was not the public taking over the private, as was the case in the 1950s art, but the private overrunning the public. Unlike the official and dissident photography of the 1970s and 1980s - with the former glorifying everyday life as an expression of political order, and the latter denouncing it with the added element of recuperative transcendence meant to redeem the banality of the quotidian - in Štreit's photographs there is no space for the private and the extraordinary outside the collective and the daily.

The blending of social spaces in Czechoslovak popular art via a particular type of aesthetic was not the sole domain of photography. Film too drew attention to its formal plainness and an almost non-artistic simplicity when representing everyday life. Retaining some of the cinematographic originality of the New Wave cinema from the previous decade but without the ostentatious experiments and political allusions, Jaroslav Papoušek's Homolka Trilogy (1969-1972), for example, or Jiří Menzel's adaptations of Bohumil Hrabal's novels, Cutting It Short (written by Hrabal in 1970, published in 1976 and turned into a film by Menzel in 1981) and The Snowdrop Festival (written in 1975, published in 1978 and made into a film in 1983) were, like Štreit's photographs, neither grim nor trivial and yet firmly rooted in the quotidian. ${ }^{1}$ Since photography does not have as strong a disposition to storytelling as film, and since everydayness rests in the moment and is averse to narrative accounts, the key cinematographic goal in relating everyday life in popular film was to undermine narrativity. The Snowdrop Festival, for example, with its pedestrian content and attention to realistic detail, made the camera linger for most of the film on mundane events such as repairing a car, waiting for the local convenience store to open, taking the goats to pasture and weeding a vegetable plot, thereby moving away from telling a story and toward a record that was merely episodic (see Figure 3).

Papoušek showed a similar tendency away from storytelling in the Homolka Trilogy. Recording a typical weekend day of a family of children, parents and grandparents, Ecce Homo Homolka, the first film in the trilogy, starts with morning mushroom-picking in the forest, followed by cooking lunch and an afternoon steeplechase, ending with an evening at home, all the while framing the scenes with dialogues that, as if taken from a Dictionnaire des Idées Reçues of Czechoslovakia of the time, come out as simultaneously genuine and empty. Nothing revelatory happens in the film and anything that would suggest the characters' development is also absent. In their interaction, the characters repeat, have always repeated and would keep repeating the same situations with the same dialogues and identical outcomes (see Figure 4).

Without the comic, this would have been indeed a bleak movie; but even with the comedy, it is not that humor simply overrides the factual and transforms the unattractive reality into something else. As with the early films of Miloš Forman, such as The 


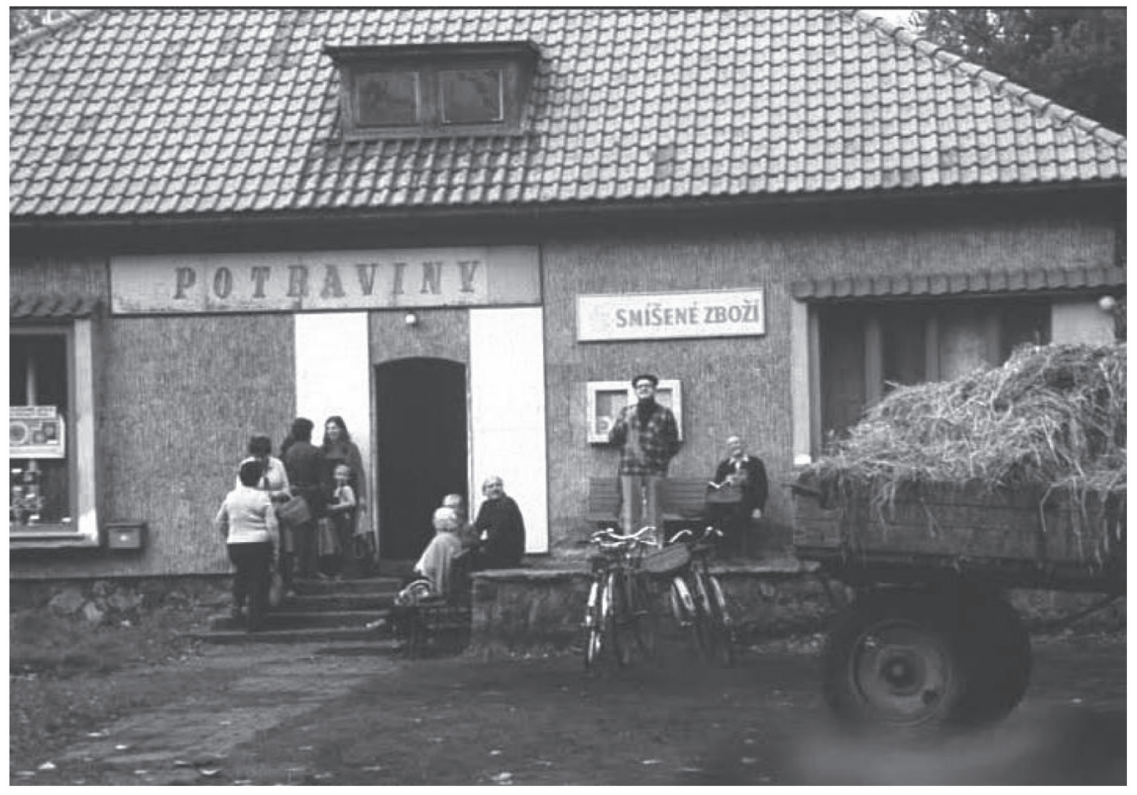

Figure 3. The Snowdrop Festival (dir. Jiří Menzel, 1983) (Reproduced with kind permission of Bontonfilm)

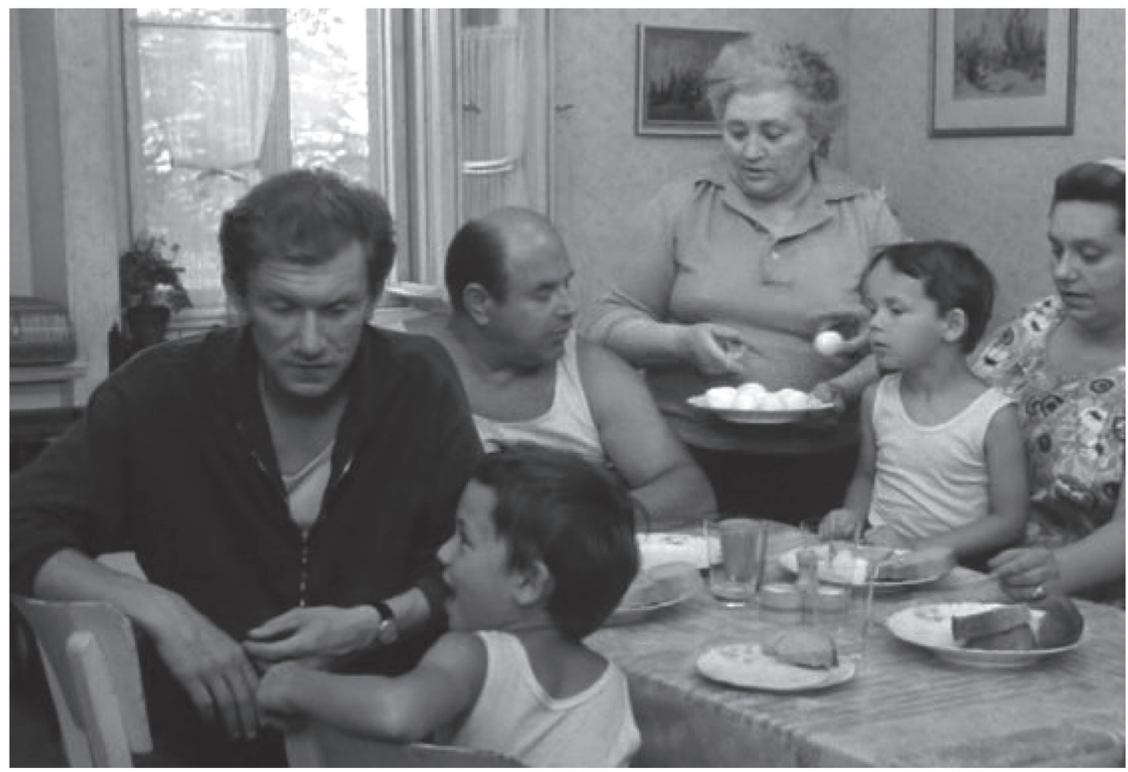

Figure 4. Ecce Homo Homolka (dir. Jaroslav Papoušek, 1969) (Reproduced with kind permission of Filmové Studio Barrandov) 
Firemen's Ball (1967), Black Peter (1964) and Competition (comprising two parts, Why Do We Need All the Brass Bands? and The Audition, 1964), the popular film of the 1970s and 1980s presented neither a bitter sarcasm, nor a self-indulgent amusement, nor a poeticizing of the mundane.

Considering the humdrum themes, the use of non-actors and the lack of an open denunciation of the dreariness of one's plight (or a suggestion of a possible escape from it), the surprising success of films such as The Snowdrop Festival and Ecce Homo Homolka stemmed from the fact that the audience did not live differently. With the high level of social homogeneity in Czechoslovakia, there was not much variation in how people lived, how they furnished their apartments and what they did in their free time. Seeing the same kind of wealth, attire, decorations, dietary customs and social and generational problems, the audience recognized the depicted condition as their own and, moreover, accepted it lightly because of the absence of the usual ideological distortion. In Štreit's photographs, Hrabal's stories and Papoušek's and Menzel's films, everydayness stayed in its place with its neutrality, neither banal nor romantically delightful, and while it preserved its mundane character, it did not lead to sentimentality, dejection or irony - all dead ends in artistic attempts to represent the quotidian.

Neither didactically complacent with the realities of political life as the official art, nor critical of them as the dissident art, the aesthetic created in Czechoslovak popular art represented everyday life without both optimism and pessimism. Downplaying the act of artistic figuration and insisting on the plainness yet fullness of what it depicted, it portrayed everydayness in such a way that its greyness coexisted on the same aesthetic plane with its frailness and subtlety, introducing neither alleviating poetic elements nor critical judgments. The light tenor that this form of representation generated did not add anything to the represented material. It merely exposed the authenticity of exactly this reality - the fact that this was the reality of those who lived in it, and that this reality was all there was to their day-to-day existence. This idiosyncratic aesthetic effect was the outcome of the artistic juxtaposition of two incongruous approaches: verisimilitude and humor. Kenneth Burke called such an effect 'comic primness' (1955: 126), describing it as a double comedy of sorts: a comic trope that turns against itself which, while producing comic undertones, refuses to institute ironic distance. Rather than ridiculing the ordinariness of the mundane, this type of humor familiarizes the audience with their human condition. With the basic premise that if this is the way that things are for everyone, then irony would be condescending, instead of resorting either to pedantic realism or ironic distance, Czechoslovak popular art turned to comic realism, showing reality with some of its absurdities but making it clear that this was the way of the world.

Due to the avant-garde art's ill-repute of elitism and pretentiousness, it was easy for the art that was not experimental or escapist to find a wide audience in Czechoslovakia. Down-to-earth works that did not surprise and looked familiar did not even give the appearance of art. Unlike the high art that displays its incompatibility with the quotidian and posits itself as beauty without practical use, this form of familiar art is domesticated and 'de-defamiliarized'. Although the general tendency among modern representations of everyday life, as Paul Fleming has argued recently, has been to 'transform it so as to produce exemplary forms of mediocrity, an averageness that both 
maintains and transfigures itself' (Fleming, 2009: 3), the aesthetic tension between mediocrity and exemplarity is absent in Czechoslovak popular art. Rather than superimposing the unusual over the ordinary and representing the mundane by aesthetically transforming it and lending it an exemplary form, Czechoslovak popular art owes more to what Stanley Cavell described as 'the familiar being invaded by another familiar' (Cavell, 1996: 232). This type of art retains ordinariness in both the portrayed material and the aesthetic effect. The moment during which this art appears is slow and gradual and its effect extended - not short, unpredictable and resisting integration, as Karl Heinz Bohrer's (1994[1981]) notion of 'suddenness' as a definition of aesthetic experience proposed. By making aesthetic experience at home in daily life, this form of art demonstrates that automatization is not necessarily art's nemesis, as the Kantian idea of the epiphanic aesthetic that suddenly interrupts everydayness suggests. Unlike the cycle of the mechanical emersion in the daily with abrupt epiphanies, 1970s and 1980s Czechoslovak popular art poses a low-intensity and long-duration aesthetic experience in which the encounter with the everyday takes place within the everyday, and in which the ability to fuse art and everydayness provides a more decentralized and undetermined pattern of aesthetic experiences than one offered by the art that presents itself as the opposite of the everyday. ${ }^{2}$

What we see in communist Czechoslovakia is a formation of a unique aesthetic that emerged as a response to the official culture and appropriated its rhetoric of everydayness with results that were far from the intended vision of pacifying the masses. There is no doubt that the systemic infrastructure of the Czechoslovak state mobilized real tensions between individuals, making intolerance and envy a daily occurrence of life under communism, as Ladislav Holy (1996) demonstrated in the example of retail-consumer relationships. It is also undeniable that the characters and characteristics that represented these antagonistic interpersonal elements were present within the public's collective recognition of the popular art that reflected everyday experience, and as such were part of the aesthetic catharsis that these works offered. However, these representations were necessarily limited due to censorship. Instead of serving as a critical tool and a means of testing the permissibility of such portrayals, popular art was a creative medium that functioned within the framework of other social practices of everyday life, and was in par with the dynamic and productive forces of popular culture in general.

Although one cannot disregard the role of changes within artistic practice as such, the increased effect of social conditions on this practice in communist countries - even if only due to the authorities' disapproval of artistic experimentation for its own sake as asocial - is undeniable. For this reason, the status of Czechoslovak popular art and the distinctiveness of its aesthetic come into full view only when seen within the context of its place and time. In fact, on its own the aesthetic of Štreit's photographs and Papoušek's films was not without precedence, resembling some of the techniques of the American social photography of the 1930s and the Italian neo-realist cinema of the 1940s. What was new about it, namely the combined effect of greyness and lightness, resided, together with the aesthetic dimension, in the way that the featured material was perceived. In other words, the meaning and the status of this art was inseparable from the social significance of the daily practices that it represented. The symbolic meanings that Czechoslovak popular art communicated, such as the destabilized division between work 
and leisure, the public and the private and the habitual and the improvised, had direct correlatives in various social and cultural practices that destabilized the same divisions in everyday life. As Michel de Certeau (1984[1980]) showed in a number of examples from cooking to taking a walk in the city, practices of everyday life always convey symbolic meaning. The general tendency is that whenever these practices hold very little symbolic creativity, art tends towards pure imagination; and whenever they are symbolically potent, art departs from pure imagination. The latter was the case in Czechoslovakia, where the art of the quotidian served as a counterpart to a social space that was saturated with symbolic communication. The fact that social and cultural practices were symbolically expressive already before entering the realm of art played a crucial role in making popular art contiguous with everyday life.

One way to explain the disposition of everyday practices in Czechoslovakia as charged with both aesthetic effects and symbolic communication is the type of political repression instituted there in the 1970s and 1980s. After the August 1968 Soviet invasion, the communist regime could not simply ignore the freedoms experienced in the 1960 s and restore the pre-1960s order. Since the people's dedication to the common political cause could no longer be expected, the regime offered material improvements and personal liberties within the confines of one's private life in exchange for quiet compliance and political stability. Although this exchange - poignantly christened by Milan Kundera (1980[1978]) as the 'forgetting principle' - was economically untenable, it was instituted despite the spiralling international debts and permanent threat of recession (Czechoslovak hard currency debt in the 1970s rose 12 times and the economy in the 1980s started shrinking; Judt, 2006). Together with the state campaign of modernization came the rhetoric of modernization. The catchy adjective 'modern' (moderni) was used freely as determination of quality for anything from apartment decoration and music to haircuts. Unlike in the 1950s, when modernity and modernization referred primarily to economic transformation and its place in the politically framed vision of the future, this new rhetoric encouraged a consumerist lifestyle rooted in the present, centred around the private space of domestic security and self-realization. Public images of success, as they appeared in mass-circulated magazines, advertisements and TV and radio shows, ceased to celebrate work and progress and instead extolled independence, novelty and cleanliness by concentrating on cars, clothes, home appliances and a range of consumer products as images of modern life.

However, despite the vigor with which modernization, with its drive to privatize existence and disable potential revolts, was promoted, its implementation was not very successful. With infamous queues for even basic products, it was clear that reality did not support the appeal to modern life. For the vast majority of people, modernity was nothing more than a magazine illustration and an empty rhetorical device that left no tangible marks on their daily lives. Nonetheless, this apparent inconsistency between the publicly disseminated symbols of modernity and the lived reality had significant social and political implications. With the desired effect of modernization turning into a failure, with any large-scale political change remaining unfeasible, the paradoxes and inconsistencies of officialdom became deterrents in people's acceptance of the ideology of modernity, allowing art and various social and cultural practices to explore them and to form popular adaptations to the status quo. 
Many of the social and cultural practices of everyday life that emerged in the communist countries were not unique to the East. As Erving Goffman showed, some of these practices - for example, 'make-work', saving work for the moment when the manager comes for an inspection, or pretending to work in case all work is completed even when one's work is measured by quotas - appeared regularly on both sides of the Iron Curtain as early as the 1950s (Goffman, 1990[1959]). However, there were other practices that played a more prominent role in the East. Some of the most emblematic included the exchange of homemade products unavailable on the market, diverse methods of resisting governmental attempts to introduce competition at workplaces, and melouch. Designating neither absenteeism nor pilfering, melouch was the kind of work done at one's workplace for oneself or an acquaintance, or sometimes outside using the employer's tools - but not commissioned by the employer. ${ }^{3}$ Instituting a network of friendly services and mutual favors, this array of practices undermined the state economy while exceeding mere personal profiteering and, together with popular art and other social activities such as 'cottage homemaking' and 'cabining', served as spontaneous and creative responses to ideological norms and concomitant systemic divisions (that is, the divide between work and leisure, activity and passivity, the communal and the personal).

Having undergone an unparalleled boom in the two decades of the so-called normalization of Czechoslovakia in the 1970s and 1980s, cabining was one of the principal social practices of everyday life and a curious phenomenon of the time. With the influx of people to cities and properties in the countryside becoming inexpensive, it became a common way of spending free time. Due to the magnitude of this practice, a multiplicity of its subforms quickly evolved, ranging from having a cottage (chalupa), usually a reconstructed peasant house in a rural village, to a cabin (chata), a newly-built wooden lodge in mountains, around lakes and in districts near cities specifically allocated for their en masse development, to a simple garden lot with a shed (zahrada), whole colonies of which grew often ad hoc at the outskirts of metropolitan areas. In the countryside, this venture not only utilized unused land and kept otherwise vacant houses inhabited, but also helped to breach the increasing demographic gap between cities and the country. What initially had begun as a retreat from the city, work and politics, soon assumed a status of an activity of its own accord. Like gardening, having a cottage or a cabin meant cottage homemaking (chalupařeni) and cabining (chatařeni): that is, an occupation and a hobby. Even though state propaganda considered hobbies to be private feats and therefore unlike one's job, meaningless as a form of public commitment, exercised by many, practices such as cabining acquired a considerable social impact - especially given the fact that, as Paulina Bren (2002) points out, by the early 1980s people were spending up to a staggering 120 days a year at their cabins and cottages.

Although the chata culture emerged in other countries as well - Nordic countries, for example or contemporary Russia, as Baschmakoff and Ristolainen's (2009) recent book on the dacha culture demonstrates - its Czechoslovak version is unusual in both historical and geographical terms. An outcome of a planned development that reflected the official policy of both yielding to people's demands (according to the rule of material improvements in exchange for political obedience), and of trying to keep all people's undertakings low-key and easily suppressible and removable, this culture took root in areas off the beaten track, often without electricity, sewage and running water. Building 
permission was strictly regulated and only small and less permanent structures using wood rather than stone and brick were allowed. Due to high demand and the insufficient land allocated, lots were small. The resulting density of people oddly repeated what this endeavor tried to evade, namely the overcrowded conditions of the urban housing districts with their unhealthy neighbor relations. However, while this culture did not immediately do away with the gossip, envy and conformity that were typical of city life, the situation of a large group of people left in basic conditions and with few distractions led to increased interaction and slowly became a catalyst for new forms of collectivities. Taking turns in fetching groceries from the nearest village shop, barbecuing and preparing meals together, engaging in collective sports and, with no television and electricity, drinking or playing cards in the evening, were among the most frequent forms of such collective activities and interactions. Interestingly enough, in the urban housing districts, a similar situation of dense population and inadequate comfort did not produce this type of collectivities - or did so only to a limited extent. Unlike everyday life in the city, the chata culture represented an exceptional, non-daily life. In the marginal spaces of cabins, cottages and gardens, people interacted more and more freely because these spaces had an out-of-the-ordinary feel, despite the fact that the simplicity of their conditions made people spend even more time on ordinary things and taking care of the bare necessities. It was the paradoxical coexistence of the exceptional and the ordinary in these spaces that revived the everyday, which particular forms of presentation in art tried to reflect and mediate.

Ironically enough, in the situation of the officially endorsed policy of cultural depoliticization, Czechoslovak popular art and practices of everyday life were not apolitical. While the nomenklatura's strategy was to fragment the populus, seal off the private from the public and relegate the private into the merely subjective, everyday and politically ineffective, the unforeseen outcome of the state's concession of absolute control was not the privatization and depoliticization of daily life. As popular photography, film and practices such as cabining show, not only was the elites' anticipation that modernization and reorganization of power would lead to the privatization of life not fulfilled, but it actually backfired as a political plan. The public realm that the state wished to secure when granting people their private domain, hoping to deprive them of a site for voicing their discontent, was reclaimed in widespread popular fashion by those who were supposed to retreat into privacy. Even though this unexpected turn meant neither freedom of expression nor the mobilization of political resistance, appropriating existing practices of everyday life to popular use engendered modes of social action that were far from merely enacting the state's agenda. As a result of this reclamation of public space, Czechoslovakia in the 1970s and 1980s became a society that was socially very cohesive despite political restrictions, with no compartmentalized groups and only minimal differences in salaries. Although the lack of competition and collapse of authority had disastrous effects on the economy, in everyday life they contributed to the social condition that rendered any display of superiority detrimental. Certainly, there were differences in class situation in economic terms between the general population and the high party officials that implied cultural heterogeneity, which, in turn, made cultural capital instrumental to social mobility, but in daily life any indication of economic and cultural superiority was treated with derision and ridicule. As Milan Šimečka (1984[1979]) provocatively suggested, with 
intelligentsia and the working class intermingling with a sense of solidarity, the communist regime in the normalized Czechoslovakia, against its effort to do exactly the opposite, actually stimulated a peculiar type of collective freedom that 'could be almost described as anarchic' (Šimečka 1984[1979]: 151). ${ }^{4}$

Replacing the compromised political verve and unwary enthusiasm of the 1950s, the popular art and practices of everyday life in Czechoslovakia after 1968 formed a conservative undercurrent to state-induced modernization. As aesthetic, cultural and social forces, these practices responded to the discrepancy between the official rhetoric of modernization and the reality of ineffectiveness and shortages by focusing exclusively on daily activities that were firmly rooted in the present. The fact that this type of everydayness was perceived as an authentic image of everyday life strengthened further the way in which the quotidian was lived and experienced. Although practices such as cabining had no major influence on official policies, let alone politics, they were not simple retreats into privacy, as critics often argue (see Možný, 1999). Together with other public rituals - such as make-work, melouch, mass performances (spartakiády), celebratory processions, exercises of voluntary firefighters and inter-factory competitions in collective sports - they generated a surprising social effect. As in popular art, where the portrayed socio-temporality remained embedded within the temporal present, and where the private overtook and inhabited the public, the social and cultural practices of everyday life brought to being everydayness that essentially, in its plainness and ordinariness, was shared.

The specific arrangement of social and political forces during the normalization period in Czechoslovakia gave rise to an everydayness that offers an important contribution to the theory of everyday life. The most fundamental tenets of this theory were formulated by Henry Lefebvre in the years following the Second World War and revised by Lefebvre and in Czechoslovakia by Karel Kosík, about 15 years later. In the early 1960s, both Lefebvre and Kosík analyzed the link between the ordinary and extraordinary in everyday life, both coming to the same conclusion: the separation between the daily and the extraordinary is the effect of modernity that inscribes these two dimensions as mutually exclusive. Kosík's explanation of this tendency - the fact that the repetitive gestures of work and consumption have erased the cycles of nights and days, activity and rest, life and death and replaced the sense of change that these cycles generate with an uninterrupted flux of daily monotony (Kosík, 1976[1963]) - is akin to Lefebvre's argument. In the second volume of Critique of Everyday Life, Lefebvre (2002[1961]) suggests that our everydayness is monotonous because the modern lifestyle has slowly eliminated extraordinary moments. Lefebvre proposes that as instances of one's experience of excitement in everyday life, moments are rooted in everydayness and determine its specific shape: without them, the everyday is just an empty form. Lefebvre's primary example of a moment is love. Love slowly emerges out of casual dialogue that gradually turns into covert flirting and ultimately into a realization that what is happening is love. Love also withers away bit-by-bit, leaving one with an indefinite feeling of the tragic. Lefebvre returns to the role of the tragic in shaping everydayness in the third volume of the Critique (2005[1981]), insisting that failure to incorporate the tragic aspects of life into daily comings and goings is the single most important reason why not only the tragic but also the exciting have all but vanished from modern life (Lefebvre, 2005[1981]). 
Notwithstanding their gloomy diagnosis, Kosík and Lefevbre hypostatize a fundamental unity of the daily and the extraordinary. Writing in 1963, in the atmosphere of political reforms in Czechoslovakia, Kosík - like Lefebvre, who would later wonder 'why wouldn't the concept of everydayness reveal the extraordinary in the ordinary' (Lefebvre, 1987[1980]: 9) - objects to the long tradition of thinkers, from Georg Simmel and Max Weber to Martin Heidegger and Theodor Adorno, who saw everydayness as a source of alienation (Kosík, 1976[1963]). According to Kosík, the everyday remains 'a product of history and a reservoir of historicity' (1976[1963]: 45), despite the fact that modernity has made it into the opposite of history, with the familiar, nearby and habitually recurring now turned into a non-historical everydayness, and all that is unknown and extraordinary becoming seen as either a transcendent reality or the intrusion of history. Trying to rehabilitate the quotidian as a site of the political, Kosík argues that although in some moments in history the bond between the everyday and the extraordinary can be concealed, no historical and social conditions are able to undo it altogether. For both Kosík and Lefebvre, the everyday never coincides with the reified objectivity of social institutions. Since it is always the people as a group who carry out the seemingly disembodied norms in daily life, the quotidian falls into a space where abstract norms are collectively enacted, and hence can never be completely privatized, depoliticized and banalized.

In spite of their confidence in people's inherent disposition to resist the historical trend of separating the daily and the extraordinary, in the 1970s and 1980s both Lefebvre and Kosík turned to emphasize the negative aspects of late modernity. Lefebvre's record of social changes in the three volumes of the Critique, covering the period from the aftermath of the Second World War until the early 1980s, draws attention to consumerism and the gradual dissipation of both the sense of the tragic and the moments that infuse everydayness with excitement. Similarly for Kosík, his earlier optimism that was affected by the politically liberating situation of the 1960 s faded into a more sceptical position. In his view, after the renewed repression in Czechoslovakia in the years following 1968, the everyday no longer offered the extraordinary version of the mundane. After dismissal from his academic posts in 1971 and confiscation of his manuscripts during a police raid on his apartment in April 1975, in June 1975 Kosík denounced everyday life in Czechoslovakia in an open letter to Jean-Paul Sartre. Published in Le Monde, this letter described everyday life under communism as an absurd existence lived in the environment of constant and all-encompassing suspicion (Kosík, 2003[1975]). Kosík and Lefebvre were, again, in agreement: the 1970s witnessed a growing social fragmentation and banalization of everydayness in both the East and West.

In examining the process of privatization of everyday life one cannot underestimate the role of the post-Second World War constellation, and indeed in many European countries the escape from the great narratives and the turn to consumerism was connected to the time and not to the social system. However, unlike in other European countries where the great narratives were abandoned after the Second World War, in Czechoslovakia such narratives were finding fertile ground exactly at that juncture. Introduced after the communist takeover in 1948, they only grew stronger in the 1950s - all the while the West was increasingly turning to consumerism - and disintegrated only after 1968, finally giving way to consumerism. Therefore it was both the time (modernity with its shift from 
production to consumption) and the social system (erosion of the official sacred in socialism) that created the specific form of privatization of everyday life under normalization. Depending on one's perspective, collective privatization in the normalized Czechoslovakia can be interpreted as either a parallel or an alternative to western consumerism: from the perspective of the development of modernity, it is a parallel because it represents a belated shift from production to consumption; and from the perspective of the social system, it is an alternative because even though as a value-determining ideology the great narrative fell apart for virtually everyone in the 1970s and 1980s, it remained the ruling political doctrine, thus making all activities, including consumerist behaviour, always a double-stance in regard to this doctrine. Marking all actions and all segments of social life, the discrepancy between the official and the personal turned consumption culture in socialism into something other than just a symptom of the shift to the privacy of consumerism. In this sense, Lefebvre, who is certainly relevant for studying the more general aspects of modernity in both capitalist and the socialist countries, does not account for the specificity and the social and cultural consequences of the shift from production to consumption in at least some socialist states.

In their analyses of everyday life in the 1970s and 1980s, Kosík and Lefebvre relied heavily on the concept of popular culture as an extension of official policies and a conduit of the historical tendencies of modernity. Focusing almost exclusively on official policies, Kosík - and to a lesser degree Lefebvre - often ignored local forms of adaptation or treated them as merely passive receptors of the status quo, assuming that the public had no agency in the process. Although Lefebvre was not entirely wrong when he concluded that what shaped everyday life in the East was 'the pressure of state ideology and internalized oppression (the ethics and aesthetics of pseudo-collectivity decreed by the state)' (2005[1981]: 52), on the level of implemented policies the East and the West had more in common than he was willing to admit. As we have seen, the East was under the same spell of state-induced modernization as the West. However, Lefebvre oversimplified not only the cause of social fragmentation in Eastern Europe, overstating the role of repression and downplaying the role of material advancements, but also its effect. Whereas individualism in France penetrated into virtually all spheres of life in the 1970s, from urban planning - home as a private space and the street as an efficient flow of traffic, as Guy Debord and the Situationists were tireless to repeat - to the new epistemological and aesthetic paradigms in philosophy, anthropology and literature, in the East the communal dimension of everyday life remained relatively strong. In the political situation when the official communist narrative of redemption was still in place but no one believed in it anymore, repression, far from being passively internalized, stimulated a range of social, cultural and artistic practices that undermined the historical thrust towards individualism described by Lefebvre and Kosík. Drawing on Lefebvre, Alice Kaplan and Kristin Ross are right to insist that it is in the midst of the ordinary where 'we must look for utopian and political aspirations to crystallize' (Kaplan and Ross, 1987: 3). However, not only aspirations crystallized in the Czechoslovak quotidian; unlike in the West, where social fragmentation led to individual alienation and thus to utopian desires, the harsh political circumstances in the East led to collective alienation and to a mode of everyday life that was, against all odds and regardless of repression, collective. 
The trouble with accepting this emphasis on popular culture and practices of everyday life when studying communist Eastern Europe is obvious: it promotes a questionable underrepresentation of the political realities of communism. Yet, it is paradoxically this emphasis on the social aspects of everyday life under communism that can explain recent phenomena such as Ostalgie and the upsurge of comically nostalgic representations of communism in contemporary East-European film. This dilemma is nothing new. With origins in the Annales School of the 1930s and 1940s, it played an important part in the discussions about historiography in the 1970s. What came out of these debates was a postulate of two types of histories: one based on major historical events and political struggles, and the other a product of everyday life as it was lived in a widespread popular fashion. Unlike history that concentrates on popular culture and is written from the perspective of the masses, historiography that focuses on crucial social events - what Fernand Braudel [1995[1949]) called histoire événementielle - is told from the viewpoint of victors of key political clashes and administrators of the resulting social transformations. Needless to say, it is the latter that has been adopted most frequently as a dominant historical discourse, not only in the West but also in the East.

Although important exceptions have emerged over the past several years that suggest a possible change of course (see Apor, 2008 and Iordachi, 2008), the prevailing history of the four decades of communism in Eastern Europe has been narrated from the viewpoint of those whose opposition to communism precipitated its overthrow. In Czechoslovakia, exemplified most notably by Václav Havel, this approach sets the link to the past on the basis of its moral assessment. Stressing the political and ethical inadmissibility of communism, this account of history denounces everyday life under communism as banal, because any form of life that did not express direct protest against the status quo was conformist and thus fraudulent. According to Havel, the 1970 s and 1980s were particularly despicable in this regard. It was 'an era of apathy and widespread demoralization, an era of gray, totalitarian and consumerist everydayness' (Havel, 1990a[1986]: 119) because people were ready to trade their private lives for the price of political concessions and because their conscience remained clear, as that was what everybody did. In 'The Power of the Powerless' (1990b[1978]), Havel famously illustrates this false moral justification with the example of a grocer who decorates the window of his store with the slogan 'Proletariat of the world, unite!' without feeling morally corrupt, because he expects everyone to know that he had to display it, regardless of what he thinks about it.

While it is evident that communism was not defeated by the silent majority, as those who criticize the current Czech president Václav Klaus for defending people's political indolence during communism and futile 'Schweiking' maintain (see Pehe, 2003; Třešňák, 2005), cultural historians should not be too quick to integrate their analyses of the quotidian in which the majority of population lived into the dominant version of history as a sequence of decisive events and evolution of political systems. From the perspective of popular culture and social and cultural practices of everyday life, with their inventive take on both the official politics and the seemingly apolitical discourse of modernization, the moral alibism in Czechoslovakia condemned by Havel was not a symptom of social fragmentation. Although morally contemptible, socially the communicative dualism of thinking one thing and saying something else, as Peter Steiner (2000) describes the logic 
underlying the grocer's message, was neither dualistic, nor was it a manifestation of political lethargy that accelerated social atomization. Unlike in dualism, where two operative registers remain mutually exclusive, under the normalized communist regime disjunctive realms of thinking and saying were experienced simultaneously. In a mechanism similar to the artistic trope of comic primness found in film and photography, under communism one did not just say what one did not believe in so as to be left alone. Although saying and thinking were not identical, the seemingly egocentric alibism of showing the necessary level of conformity familiarized people with their condition and fostered a sense of complicity and collectivity.

The collective and its psychological mobilization against the state - as an apolitical outcome of everyday lived experience, not a form of collective political identification suggests that the privatized collectivity could be theoretically linked as much to the seemingly apolitical masses as to Havel's notion of unpolitical politics. The only problem is that although Havel's unpolitical politics does not entail direct political opposition to the state, its message of 'living in truth' implies non-acceptance of everyday life under communism, thereby stimulating either individualism or a collectivity of small groups whose existence is defined by their rejection of the popular culture of the masses. Even though the social and cultural practices of everyday life that emerged in Czechoslovakia did not challenge the political elite, their adaptation to its restrictive rules generated everydayness that was neither individualistic nor negating. In the political environment of enforced and often arbitrary rules, the feeling of affirmation that, as Agnes Heller notes, 'accompanies and permeates our physical and mental state' (1984: 251) and which she attributes exclusively to everyday life, was not a positively given inner emotion and a private answer to modern alienation. It was an outcome of a collective response to the contradictions of modern life and an emotion based on common subsistence. At the time when open distance from the official doctrine out of moral conviction, or concealed distance out of cowardice to express one's discontent publicly, were assumed even by the rulers, the relationship of proximity to ideology disentangled people from their competition with each other and from their responsibility for the system and its future. ${ }^{5}$ Surprisingly, this acceptance of necessity as a chosen option - in a twist on the Kantian 'one can because one must', and even for the price of performing empty rituals - generated everydayness that was shared.

Without challenging the status quo with the vision of how things should be and how the quotidian, when measured against this ideal, proves petty, popular culture and practices of everyday life always beget modes of inhabiting the social space in ways that preclude the state agenda from permeating the whole fabric of society. In the case of Czechoslovakia in the 1970s and 1980s, popular culture fashioned everydayness that was neither opposed to the regime nor compliant with it. Instead of the recourse to something beyond that would redeem the banality of the quotidian - freedom, justice, future, beauty, God - and that would give the mundane an exemplary form and art a didactic function, popular culture emphasized the familiarity, immanence and ordinariness of both reality and its representation. The result was an art that extended aesthetic experiences to everyday cultural and social practices, thereby decentralizing the aesthetic per se. Although undermining aesthetic autonomy and weakening the incompatibility between aesthetic experience and the everyday has its own pitfalls - Martin Jay has 
recently reiterated the danger of an 'unmediated reality becoming fair game for aesthetization' (2003: 19) in the trend of destabilizing the link between aesthetic experience and the artwork - the expanded realm of aesthetic experience opened up by Czechoslovak popular art brought neither the feared politicization of aesthetics, nor an aestheticization of politics. Instead, it created the kind of aesthetic experience that was slow and prolonged. Showing that art that wishes to capture everydayness is in a mutually constitutive relation with the social practices of everyday life, this proliferation of aesthetic encounters that Czechoslovak film and photography stimulated reveals that such an art cannot set itself as a domain separate from the daily. Even though Peter Brooks (1994) is right to point out that shifting too rapidly from art to the generic notion of culture runs the risk of destroying the specificity of the aesthetic dimension, Czechoslovak popular art draws attention to the aesthetic form that is inextricably intertwined with culture, which cannot be understood outside everyday practices. Unlike the epiphanic aesthetics of suddenness which, as Karl Heinz Bohrer argued, creates a 'utopia of the moment' (1994[1981]: 232) - because the suddenness that breaks in, while ungraspable and unsustainable, still manages to take place (precisely by interrupting the moment) - the slowness and ordinariness of the aesthetic of everydayness in Czechoslovak art is neither ecstatic, nor negative, nor utopian. The moment opened up by this aesthetic actually occurs: scarcely standing out and barely registered, it remains ordinary and without the pathos of conclusiveness, finality and accomplishment and with no need of emancipating elements, it opens up everydayness as an end in itself.

\section{Funding}

This research received no specific grant from any funding agency in the public, commercial or not-for-profit sectors.

\section{Notes}

1. It should be noted that some of Hrabal's and Menzel's works from this time were more directly political. Hrabal's I Served the King of England (written in 1971; 1990a[1982]) and Too Loud a Solitude (written between 1972 and 1976; 1990b[1980]) departed from everyday life and, with their political references, became unacceptable to state censorship. Menzel crossed the threshold of political permissibility in his 1969 film adaptation of Hrabal's stories, Larks on a String, which was immediately seized and finally released only in 1989.

2. Hans Ulrich Gumbrecht (2006) elaborates on this form of aesthetic, extending it to the experience of everyday objects such as a new chair or new software.

3. Michel de Certeau discusses melouch as la perruque (see De Certeau, 1984[1980]: 25-26).

4. It is important to emphasize that Šimečka was no defender of the political system, and that as a key figure of the reformist movement in the 1960s he was stripped of his academic positions after the Soviet invasion and forced to work in menial jobs.

5. Slavoj Žižek $(1989,1997)$ describes a similar principle when commenting on a too-literal and thus empty gesture of identification with ideology, which makes the latter the sole guarantor of a smooth running of things and the only responsible party in case of their failure.

\section{References}

Apor P (2008) The joy of everyday life: Microhistory and the history of everyday life in the socialist dictatorships. East Central Europe 35(1-2): 185-218. 
Baschmakoff N and Ristolainen M (eds) (2009) The Dacha Kingdom: Summer Dwellers and Dwellings in the Baltic Area. Helsinki: Kikimora Publications.

Bohrer KH (1994[1981]) Suddenness: On the Moment of Aesthetic Appearance. New York: Columbia University Press.

Braudel F (1995[1949]) The Mediterranean and the Mediterranean World in the Age of Philip II. Berkeley, CA: University of California Press.

Bren P (2002) Weekend gateways: The Chata, the Tramp and the politics of private life in post1968 Czechoslovakia. In: Crowley D and Raid SE (eds) Socialist Spaces: Sites of Everyday Life in the Eastern Bloc. Oxford: Berg, pp.123-140.

Brooks P (1994) Aesthetics and ideology: What happened to poetics? Critical Inquiry 20(3): $509-523$.

Burke K (1955) A Rhetoric of Motives. New York: George Braziller.

Cavell S (1996) Declining decline: Wittgenstein as a philosopher of culture. In: Mulhall S (ed.) The Cavell Reader. Oxford: Blackwell, pp.321-352.

De Certeau M (1984[1980]) The Practice of Everyday Life. Berkeley, CA: University of California Press.

Fleming P (2009) Exemplarity and Mediocrity: The Art of the Average from Bourgeois Tragedy to Realism. Stanford, CA: Stanford University Press.

Goffman E (1990[1959]) The Presentation of Self in Everyday Life. London: Penguin.

Gumbrecht HU (2006) Aesthetic experience in everyday worlds: Reclaiming an unredeemed utopian motif. New Literary History 37(2): 299-318.

Havel V (1990a[1986]) Disturbing the Peace. New York: Vintage Books.

Havel V (1990b[1978]) The power of the powerless. In: Havel V and Keane J (eds) The Power of the Powerless. Citizens Against the State in Central-Eastern Europe. New York: ME Sharpe Press, pp.29-96.

Heller A (1984) Everyday Life. New York: Routledge.

Holy L (1996) The Little Czech and the Great Czech Nation. Cambridge: Cambridge University Press.

Hrabal B (1990a[1982]) I Served the King of England. New York: Vintage International.

Hrabal B (1990[1980]) Too Loud a Solitude. San Diego, CA: Harcourt Brace Jovanovich.

Iordachi C (2008) Reconceptualizing the social: East Central Europe and the new sociocultural history. East Central Europe 35(1-2): 1-35.

Jay M (2003) Drifting into dangerous waters: The separation of aesthetic experience from the work of art. In: Matthews PR and McWhirter DB (eds) Aesthetic Subjects. Minneapolis, MN: University of Minnesota Press, pp.3-27.

Judt T (2006) Postwar: History of Europe Since 1945. New York: Penguin Books.

Kaplan A and Ross K (1987) Introduction to a special issue on everyday life. Yale French Studies 73(1): $1-4$.

Kosík K (1976[1963]) Dialectics of the Concrete. Dordrecht: D Reidel Publishing Company.

Kosík K (2003[1975]) Correspondance avec Jean-Paul Sartre. In: Kosík K, La Crise des temps modernes. Dialectique de la morale. Paris: Éditions de la Passion, pp.95-100.

Kundera M (1980[1978]) The Book of Laughter and Forgetting. New York: Alfred A. Knopf.

Možný I (1999) Proč tak snadno... Některé rodinné důvody sametové revoluce. Sociologický ese j [Why So Easily... A Sociological Essay on Some Family Reasons for the Velvet Revolution]. Prague: Nakladatelství slon.

Lefebvre H (1987[1980]) The everyday and everydayness. Yale French Studies 73(1): 7-11.

Lefebvre H (2002[1961]) Critique of Everyday Life, vol. 2. London: Verso.

Lefebvre H (2005[1981]) Critique of Everyday Life, vol. 3. London: Verso. 
Pehe J (2003) Rehabilitace normalizace [Rehabilitation of normalization]. Listy: Časopis pro politickou kulturu a občanský dialog 33(6): 84-85.

Sheringham M (2006) Everyday Life: Theories and Practices from Surrealism to the Present. Oxford: Oxford University Press.

Šimečka M (1984[1979]) The Restoration of Order: The Normalization of Czechoslovakia. London: Verso.

Steiner P (2000) The Deserts of Bohemia. Ithaca, NY: Cornell University Press.

Třešńák V (2005) Rozhovor s Vlastou Třešňákem [Interview with Vlasta Třešňák]. Hospodářské noviny, 8 August, np.

Žižek S (1989) The Sublime Object of Ideology. London: Verso.

Žižek S (1997) The Plague of Fantasies. London: Verso.

\section{Biographical note}

Daniel Just is Assistant Professor of Political Science at Bilkent University. His academic interests include the modern novel, literary theory, political theory and issues of Cold War culture and the interaction between art and politics. Some of his recent research has appeared in New Literary History, Modern Language Review, MLN: Modern Language Notes, French Forum, Romanic Review and Forum for Modern Language Studies. 